\title{
UKLAD KOGENERACYJNY PRZY WSPÓŁPRACY POMP CIEPŁA Z KOTŁOWNIĄ OLEJOWĄ I SIECIĄ CIEPŁOWNICZĄ
}

\begin{abstract}
W niniejszym opracowaniu przedstawiono możliwość zastosowania układu kogeneracyjnego przy współpracy pomp ciepła z kotłownią olejową i siecią ciepłowniczą. W procesie badawczym objęto odzysk ciepła odpadowego z silnikiem Stirlinga. Odzyskane ciepło odpadowe ze spalin kotłowych zużyte jest do napędu silnika Stirlinga, który napędza prądnicę. Wykonano obliczenia bilansu energetycznego. Obliczone wartości średniej temperatury spalin $T_{s r}$ i temperatury otoczenia $T_{o t}$ pozwalają wyznaczyć aktualną sprawność silnika Stirlinga. Wykonany bilans energetyczny oszacowuje ilość możliwej do wytworzenia energii elektrycznej. Ilość ta jest mocno zróżnicowana dla różnych wartości zewnętrznej temperatury otoczenia. Opisano bilans energetyczny dla przypadku, gdy kotłownia sama w całości pokrywa zapotrzebowanie na ciepło. Scharakteryzowano współpracę kotłowni z pompami ciepła. Rozpatrzono pięć wariantów współpracy, wyznaczonych mocą cieplną zainstalowanych pomp ciepła. W każdym z tych wariantów inne są wartości wytworzonej mocy oraz energii elektrycznej z odzysku ciepła. Moc i energia elektryczna może być wykorzystana do napędu pomp ciepła, ewentualnie do pokrycia innych potrzeb. Przeprowadzono analizę wyników obliczeń dotyczących mocy i energii elektrycznej wytworzonych z odzysku ciepła odpadowego ze spalin kotłowych oraz mocy i energii elektrycznej potrzebnych do napędu pomp ciepła. Z analizy wyników obliczeń zawartych w tabeli 1 dotyczącej wytworzonej mocy i energii elektrycznej w sezonie grzewczym, wynika, że ogółem energia elektryczna z odzysku ciepła odpadowego ze spalin wynosi $E_{e l}=18238,88 \mathrm{kWh} / \mathrm{a}$. Natomiast największa, uzyskana z odzysku ciepła odpadowego ze spalin, moc mechaniczna silnika Stirlinga jest równa $N_{m s t i r}=8,04 \mathrm{~kW}$. Wartość ta pozwala określić moc znamionową silnika do zastosowania w badanym obiekcie.
\end{abstract}

Słowa kluczowe: bilans energetyczny, silnik Stirlinga, odzysk ciepła, spaliny kotłowe, moc, energia, sprawność.

\section{Wprowadzenie}

Badaniem objęto zastosowanie silnika Stirlinga do wykorzystania ciepła odpadowego ze spalin w kotłowni GWSA w celu wytworzenia energii elektrycznej, która może być wykorzystana na potrzeby własne obiektów szkoły.

\footnotetext{
${ }^{1}$ Tadeusz Noch, Katedra Nauk Technicznych Gdańskiej Szkoły Wyższej, 80-656 Gdańsk, ul. Wydmy 3, tel. 602130 709, e-mail: gsw@gsw.gda.pl
} 
Jedną z koncepcji modernizacji układu ogrzewania pomieszczeń w budynkach jest zastosowanie pomp ciepła współpracujących z kotłownią i siecią ciepłowniczą. Energia elektryczna wytworzona za pośrednictwem silnika Stirlinga mogłaby zostać wykorzystana do napędu silników elektrycznych w pompach ciepła.

Wykonano bilans energetyczny instalacji wytwarzającej energię elektryczną uzyskaną z odzysku ciepła ze spalin kotłowych. W obliczeniach oszacowano możliwą do uzyskania moc silnika Stirlinga, moc elektryczną prądnicy oraz wytworzoną w sezonie grzewczym energię elektryczną. Podstawą do obliczeń jest obliczona w okresie grzewczym moc cieplna kotłowni: moc szczytowa i moc zmienna w czasie.

Dodatkowo w bilansie uwzględniono możliwość współpracy kotłowni z pompami ciepła w założonych wariantach współpracy. Do obliczeń wykorzystano, między innymi program symulacyjny współpracy kotłowni i lokalnej sieci ciepłowniczej z pompami ciepła, opisany w [1].

\section{Odzysk ciepła odpadowego z silnikiem Stirlinga}

W kotłowni GWSA pracują kotły wodne opalane olejem opałowym. Odzyskane ciepło odpadowe ze spalin kotłowych zużyte jest do napędu silnika Stirlinga, który napędza prądnicę. Schemat przepływów energetycznych przedstawiono na rys. 1.

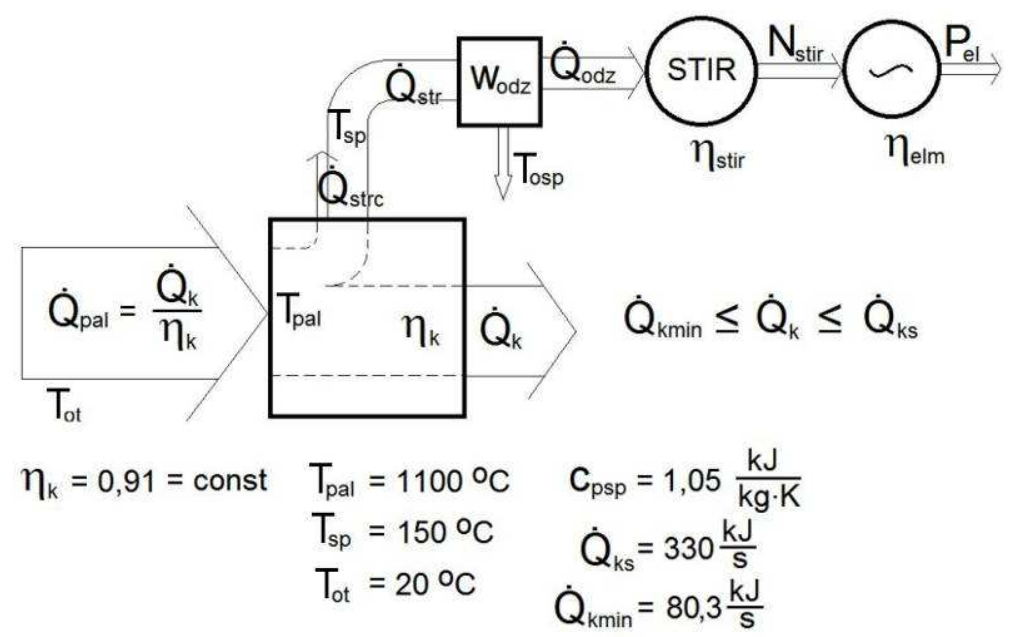

Rys. 1. Schemat przepływów energetycznych w układzie produkcji energii elektrycznej z odzysku ciepła odpadowego ze spalin kotłowych z wykorzystaniem silnika Stirlinga

Fig. 1. Scheme of energy flows in the electricity production system based on waste heat recovery from boiler fumes using the Stirling engine 
W dokonanych badaniach do sformułowanego algorytmu i do wykonanych obliczeń przyjmuje się opisane w opracowaniu poniższe założenia.

1. Moc cieplna kotła $-\dot{Q}_{k}-$ zmienia się w zakresie wartości

$$
\begin{aligned}
& \dot{\mathrm{Q}}_{\mathrm{kmin}} \leq \dot{\mathrm{Q}}_{\mathrm{k}} \leq \dot{\mathrm{Q}}_{\mathrm{ks}} \\
& \dot{\mathrm{Q}}_{\mathrm{ks}}=330 \mathrm{~kW}, \quad \dot{\mathrm{Q}}_{\mathrm{kmin}}=82,5 \mathrm{~kW}
\end{aligned}
$$

2. Sprawność kotła jest założona jako stała, niezależna od jego obciążenia cieplnego:

$$
\eta_{k}=0,91=\text { const }
$$

W kotłowni zainstalowane są kotły wodne Viessmanna opalane olejem opałowym. Sprawność kotłów zmienia się ze zmianą obciążenia, ale zmiany te są stosunkowo nieduże. Ilustracja zmian sprawności kotłów Viessmanna przedstawiono w publikacjach [2, 3]. Sprawności kotłów są wyższe, niż opisana powyżej przyjęta wartość do obliczeń. Założono taką sprawność na podstawie danych w katalogach GWSA [4], przyjmując dodatkowe założenie, że w trakcie eksploatacji pomiędzy przeglądami, sprawność tych kotłów będzie nieznacznie niższa od danych katalogowych.

3. Temperatura spalin w palenisku kotłowym jest równa:

$$
T_{p a l}=1100^{\circ} \mathrm{C}=\text { const }
$$

Wartość tę przyjęto po przeanalizowaniu danych zawartych w publikacjach $[2,3]$.

4. W obliczeniach założono, że wysokotemperaturowy wymiennik silnika Stirlinga będzie zainstalowany w strumieniu spalin na wylocie z kotła, bez dokonywania jakichkolwiek zmian konstrukcyjnych w ciągu spalin w kotle. Podobnie jak w założeniu 3 przyjęto kolejne założenie dla uproszczenia algorytmu obliczeniowego, że temperatura spalin na wylocie z kotła $-T_{s p}-$ jest stała, niezależna od cieplnego obciążenia kotła:

$$
T_{s p}=150^{\circ} \mathrm{C}=\text { const }
$$

5. Ciepło właściwe spalin jest równe $c_{p s p}=1,05 \frac{\mathrm{kJ}}{\mathrm{kg} \cdot \mathrm{K}}$.

6. Zewnętrzna temperatura otoczenia $-T_{o t}$ - jest zmienna w sezonie grzewczym. Zakres tej zmienności wyznaczają: minimalna temperatura obliczeniowa dla pierwszej strefy klimatycznej - równa $-16^{\circ} \mathrm{C}$ oraz temperatura kończąca sezon grzewczy, której wartość wybrano $12^{\circ} \mathrm{C}$ :

$$
-16^{\circ} \mathrm{C} \leq T_{o t} \leq 12^{\circ} \mathrm{C}
$$

Poszczególne wartości temperatury z podanego zakresu zmienności mają w strefie klimatycznej Trójmiasta zadany czas trwania.

7. Stopień odzysku ciepła odpadowego ze spalin w wysokotemperaturowym wymienniku silnika Stirlinga:

$$
w_{\text {odz }}=0,8=\text { const }
$$


8. Sprawność silnika Stirlinga $-\eta_{\text {stir }}$ - jest uzależniona od danych konstrukcyjnych silnika oraz od danych eksploatacyjnych: stopnia obciążenia silnika, a także od wartości temperatury gorącego i zimnego źródła, na których pracuje silnik.

W procesie odbioru ciepła wartość temperatury spalin w wymienniku ulega zmianie. Przyjęto, że temperatura gorącego źródła $-T_{s r}$ - jest średnią arytmetyczną $\mathrm{z}$ wartości temperatury spalin na wlocie do wymiennika $-T_{s p}$ i temperatury na wylocie $\mathrm{z}$ wymiennika $-T_{o s p}$ :

$$
T_{s r}=\frac{T_{s p}+T_{o s p}}{2}
$$

Do obliczeń przyjęto dane konstrukcyjne silnika Stirlinga według informacji z literatury przedmiotu [5 oraz $6 \div 15]$.

a) czynnikiem roboczym jest hel, dla którego wykładnik adiabaty przyjmuje wartość $\kappa=1,66$;

b) stopień sprężania w silniku założono $\varepsilon=20$;

c) stopień regeneracji ciepła w obiegu cieplnym silnika założono $\rho=0,7$.

Powyższe dane są włączone do przedstawionej niżej zależności opisującej sprawność silnika Stirlinga [5]:

$$
\eta_{\text {stir }}=\frac{(\kappa-1) \cdot\left(1-c_{x}\right) \cdot \ln \varepsilon}{(\kappa-1) \cdot \ln \varepsilon+\left(1-c_{x}\right) \cdot(1-\rho)}
$$

gdzie: $\quad c_{x}=\frac{T_{o t}+273,15}{T_{s r}+273,15}$

$T_{o t}$ - temperatura otoczenia, $\left[{ }^{\circ} \mathrm{C}\right]$;

$T_{s r}$ - średnia wartość temperatury spalin w wysokotemperaturowym wymienniku ciepła silnika, opisana wzorem $(7),\left[{ }^{\circ} \mathrm{C}\right]$;

$\varepsilon$ - stopień sprężania helu;

$\rho$ - stopień regeneracji ciepła w obiegu cieplnym silnika.

\section{Obliczenia i wyniki obliczeń bilansu energetycznego}

Kocioł wodny oddaje do lokalnej sieci ciepłowniczej moc cieplną $-\dot{Q}_{k-}$ zmienną $\mathrm{w}$ czasie, zależną od zewnętrznej temperatury otoczenia w okresie sezonu grzewczego. Zgodnie $\mathrm{z}$ algorytmem obliczeń i wynikami obliczeń bilansu energetycznego [1] analizie poddano otrzymaną moc elektryczną $P_{e l}[\mathrm{~kW}]$ oraz wytworzoną energię elektryczną $E_{e l}[\mathrm{kWh} / \mathrm{a}]$. Obliczone wartości średniej temperatury spalin $T_{s r}$ i temperatury otoczenia $T_{o t}$ pozwalają wyznaczyć aktualną sprawność silnika Stirlinga - według zależności (8). Moc mechaniczną silnika obliczono według wzoru: 


$$
N_{s t i r}=\dot{Q}_{o d z} \cdot \eta_{s t i r}=\frac{w_{o d z} \cdot u_{s t r} \cdot m \cdot \dot{Q}_{k s} \cdot\left(1-\eta_{k}\right)}{\eta_{k}} \cdot \eta_{s t i r}
$$

gdzie:

$u_{s t r}-$ udział strat cieplnych (mocy cieplnej) w spalinach w odniesieniu do całkowitych strat kotła - przyjęto: $u_{s t r}=0,98$.

Moc elektryczna, przy założeniu sprawności elektromechanicznej prądnicy $\eta_{\text {elm }}=0,95$ :

$$
P_{e l}=N_{s t i r} \cdot \eta_{e l m}=\frac{w_{o d z} \cdot u_{s t r} \cdot m \cdot \dot{Q}_{k s} \cdot\left(1-\eta_{k}\right)}{\eta_{k}} \cdot \eta_{s t i r} \cdot \eta_{e l m}
$$

Powyższe zależności dotyczą jednej $\mathrm{z}$ wybranych wartości zewnętrznej temperatury otoczenia w sezonie grzewczym. Do obliczeń bilansu energetycznego przyjęto zmienność tej temperatury, jak pokazano w (5), a każda z tych wartości ma zadany czas trwania. Zewnętrzna temperatura otoczenia narzuca moc cieplną kotła $-\dot{Q}_{k}$, wynikającą z zapotrzebowania na ogrzewanie pomieszczeń. Moc cieplna kotła może być obliczana z wykorzystaniem chwilowego stopnia obciążenia - wskaźnika eksploatacyjnego szeroko stosowanego w energetyce. Moc cieplną kotła dla poszczególnych wartości temperatury otoczenia oraz wartości stopnia obciążenia uwzględniono w obliczeniach bilansu energetycznego. Wartości mocy cieplnej kotła i wartości chwilowego stopnia obciążenia cieplnego kotła dla zadanych wartości zewnętrznej temperatury otoczenia kształtują się następująco:

1. moc cieplna kotła $Q_{k}$ od 330 do $80 \mathrm{~kW}$;

2. stopień obciążenia $m$ od 1,0 do 0,243 ;

3. zewnętrzna temperatura otoczenia od $T_{o t}=-16$ do $12^{\circ} \mathrm{C}$.

W obliczeniach bilansu energetycznego wyróżnionych jest 29 przedziałów czasowych; w każdym z nich wytwarzana jest energia elektryczna. Całkowita ilość wytworzonej energii elektrycznej w sezonie grzewczym ostatecznie opisana jest wzorem:

$$
E_{\text {elc }}=\sum_{j=1}^{29} E_{e l j}=\sum_{j=1}^{29} P_{e l j} \cdot \Delta \tau j
$$

gdzie wartość mocy $-P_{e l j}-$ w każdym z 29 przedziałów czasowych opisana jest wzorem (10). Końcowe wyniki obliczeń wytworzonej mocy elektrycznej i energii elektrycznej w sezonie grzewczym zestawiono w tabeli 1. 
Tabela 1. Wytworzona moc i energia elektryczna w sezonie grzewczym

Table 1. Power and electricity created during the heating season

\begin{tabular}{|c|c|c|c|}
\hline $\begin{array}{c}\text { Temperatura oto- } \\
\text { czenia }\end{array}$ & $\begin{array}{c}\text { Moc silnika Stir- } \\
\text { linga } N_{\text {stir }} \\
{[\mathrm{kW}]}\end{array}$ & $\begin{array}{c}\text { Moc elektryczna } \\
\text { z odzysku ciepła } \\
\text { odpadowego } \\
\text { ze spalin } \\
{[\mathrm{kW}]}\end{array}$ & $\begin{array}{l}\text { Wytworzona ener- } \\
\text { gia elektryczna } \\
\text { z odzysku ciepła } \\
\text { odpadowego } \\
\text { ze spalin } \\
\text { [kWh/a] }\end{array}$ \\
\hline-16 & 8,04 & 7,64 & 183,43 \\
\hline-15 & 7,77 & 7,38 & 177,16 \\
\hline-14 & 7,49 & 7,12 & 170,97 \\
\hline-13 & 7,23 & 6,87 & 164,84 \\
\hline-12 & 6,96 & 6,62 & 158,79 \\
\hline-11 & 6,70 & 6,37 & 152,81 \\
\hline-10 & 6,44 & 6,12 & 293,81 \\
\hline-9 & 6,18 & 5,88 & 352,67 \\
\hline-8 & 5,93 & 5,64 & 202,96 \\
\hline-7 & 5,68 & 5,40 & 388,85 \\
\hline-6 & 5,44 & 5,17 & 372,00 \\
\hline-5 & 5,19 & 4,94 & 473,82 \\
\hline-4 & 4,95 & 4,71 & 564,91 \\
\hline-3 & 4,72 & 4,48 & 645,50 \\
\hline-2 & 4,48 & 4,26 & 715,80 \\
\hline-1 & 4,25 & 4,04 & 776,03 \\
\hline 0 & 4,02 & 3,83 & 1010,06 \\
\hline 1 & 3,80 & 3,61 & 1127,32 \\
\hline 2 & 3,58 & 3,40 & 1225,24 \\
\hline 3 & 3,36 & 3,20 & 1380,98 \\
\hline 4 & 3,15 & 2,99 & 1508,50 \\
\hline 5 & 2,94 & 2,79 & 1943,55 \\
\hline 6 & 2,73 & 2,59 & 1183,28 \\
\hline 7 & 2,53 & 2,40 & 806,54 \\
\hline 8 & 2,32 & 2,21 & 583,17 \\
\hline 9 & 2,13 & 2,02 & 484,94 \\
\hline 10 & 1,93 & 1,84 & 440,47 \\
\hline 11 & 1,74 & 1,65 & 396,73 \\
\hline 12 & 1,56 & 1,47 & 363,73 \\
\hline & & $\Sigma=$ & 18238,88 \\
\hline
\end{tabular}

Z analizy wyników obliczeń zawartych w tabeli 1 dotyczącej wytworzonej mocy i energii elektrycznej w sezonie grzewczym, wynika, że ogółem energia elektryczna $\mathrm{z}$ odzysku ciepła odpadowego ze spalin wynosi $E_{e l}=18238,88$ $\mathrm{kWh} / \mathrm{a}$. Z przeprowadzonych badań uzyskano istotne informacje w zastosowaniu praktycznym silnika Stirlinga. 
Układ kogeneracyjny przy współpracy pomp ciepła z kotłownią olejową i siecią... 341

1. Największa, uzyskana z odzysku ciepła odpadowego ze spalin, moc mechaniczna silnika Stirlinga jest równa $N_{m s t i r}=8,04 \mathrm{~kW}$. Ta wartość liczbowa pozwala określić moc znamionową silnika Stirlinga, który można zamówić u wybranego producenta.

2. Silnik Stirlinga w zaproponowanym układzie ogrzewania pracuje na stosunkowo małych wartościach temperatury źródła gorącego. Uzyskanie znacznego odzysku ciepła ze spalin wymaga zastosowania wymiennika ciepła o stosunkowo dużej powierzchni wymiany ciepła.

3. Wykonany bilans energetyczny oszacowuje ilość możliwej do wytworzenia energii elektrycznej. Ilość ta jest mocno zróżnicowana dla różnych wartości zewnętrznej temperatury otoczenia. Zróżnicowanie to wynika z niżej opisanych powodów:

a) czas trwania poszczególnych wartości zewnętrznej temperatury otoczenia jest zróżnicowany. Najdłuższy czas trwania przypada dla temperatury $T_{o t}$ $=5^{\circ} \mathrm{C}$; jest to 696 godzin $\mathrm{w}$ roku i $\mathrm{w}$ tych warunkach, ze względu na czas trwania, jest największa produkcja energii elektrycznej (1943 kWh/a). Drugi co do wielkości czas trwania - 504 godziny w roku przypada dla temperatury $T_{o t}=4^{\circ} \mathrm{C}$ i tu oszacowana produkcja energii elektrycznej jest równa $1508 \mathrm{kWh} / \mathrm{a}$ (tabela 1 );

b) zmieniają się wartości temperatury źródła zimnego i źródła gorącego. Im większa jest ta różnica, tym jest lepsza sprawność silnika Stirlinga i, w rezultacie, tym lepszy stopień wykorzystania ciepła odpadowego ze spalin.

4. Złożenie czasu trwania poszczególnych wartości zewnętrznej temperatury otoczenia oraz oszacowanej produkcji energii elektrycznej może zasugerować przyjęcia poziomu odniesienia w projektowaniu urządzeń instalacji odzyskowej. Optymalny dobór urządzeń (na przykład powierzchnia wymiany ciepła i lokalizacja wymienników ciepła) przypadnie dla warunków panujących w temperaturze otoczenia $T_{o t}=5 \operatorname{lub} 4^{\circ} \mathrm{C}$.

\section{Współpraca kotłowni z pompami ciepła}

W opracowaniu opisano bilans energetyczny dla przypadku, gdy kotłownia sama w całości pokrywa zapotrzebowanie na ciepło. W badaniach nad modernizacją układu ogrzewania w GWSA uwzględnione są warianty współpracy kotłowni z pompami ciepła. W takich przypadkach część mocy cieplnej dostarczanej do odbiorcy przejmują pompy ciepła, a kotłownia pracuje zmniejszoną mocą cieplną. W rezultacie w kotłowni zmniejszone jest zapotrzebowanie na paliwo, zmniejszona jest ilość strat cieplnych w spalinach i w ostateczności zmniejszona jest ilość wytworzonej energii elektrycznej z odzysku ciepła odpadowego.

Rozpatrzono pięć wariantów współpracy, wyznaczonych mocą cieplną zainstalowanych pomp ciepła. Moc pompy ciepła: $Q_{p c}=13,5 ; 27 ; 40,5 ; 54$ i 67,5 $\mathrm{kW}$. Natomiast $\mathrm{w}$ zestawieniu tabelarycznym zostały uwzględnione trzy warianty, tj. dla mocy pomp ciepła $Q_{p c}=13,5 ; 27$ i $40,5 \mathrm{~kW}$. 
W każdym z tych wariantów inne są wartości wytworzonej mocy oraz energii elektrycznej z odzysku ciepła. Moc i energia elektryczna może być wykorzystana do napędu pomp ciepła, ewentualnie do pokrycia innych potrzeb własnych GWSA. Wyniki obliczeń, wykonanych według opisanego wyżej algorytmu matematycznego oraz wykonanych z wykorzystaniem programu symulacyjnego [1], zestawiono w tabelach 2 i 3 .

Tabela 2. Moc elektryczna wytworzona z odzysku ciepła odpadowego ze spalin kotłowych oraz moc elektryczna potrzebna do napędu pomp ciepła

Table 2. Electric power produced from the recovery of waste heat from boiler fumes and electric power necessary to propel a heat pump

\begin{tabular}{|c|c|c|c|c|c|c|}
\hline \multirow[b]{2}{*}{$\begin{array}{c}\text { Tempera- } \\
\text { tura ze- } \\
\text { wnętrzna } \\
\text { otoczenia } \\
t_{o t} \\
{\left[{ }^{\circ} \mathrm{C}\right]}\end{array}$} & \multicolumn{2}{|c|}{$Q_{P C}=13,5 \mathrm{~kW}$} & \multicolumn{2}{|c|}{$Q_{P C}=27,0 \mathrm{~kW}$} & \multicolumn{2}{|c|}{$Q_{P C}=40,5 \mathrm{~kW}$} \\
\hline & $\begin{array}{l}\text { Moc wy- } \\
\text { tworzona }\end{array}$ & $\begin{array}{c}\text { Moc po- } \\
\text { trzebna } \\
\text { (wartość rze- } \\
\text { czywista) } \\
{[\mathrm{kW}]}\end{array}$ & $\begin{array}{l}\text { Moc wy- } \\
\text { tworzona }\end{array}$ & $\begin{array}{c}\text { Moc po- } \\
\text { trzebna } \\
\text { (wartość rze- } \\
\text { czywista) } \\
{[\mathrm{kW}]}\end{array}$ & $\begin{array}{l}\text { Moc wy- } \\
\text { tworzona }\end{array}$ & $\begin{array}{c}\text { Moc po- } \\
\text { trzebna } \\
\text { (wartość rze- } \\
\text { czywista) } \\
{[\mathrm{kW}]}\end{array}$ \\
\hline-16 & 7,33 & 3,85 & 7,02 & 7,88 & 6,70 & 12,09 \\
\hline-15 & 7,07 & 3,79 & 6,76 & 7,76 & 6,45 & 11,91 \\
\hline-14 & 6,82 & 3,74 & 6,51 & 7,65 & 6,20 & 11,74 \\
\hline-13 & 6,56 & 3,69 & 6,26 & 7,54 & 5,95 & 11,57 \\
\hline-12 & 6,31 & 3,64 & 6,01 & 7,44 & 5,71 & 11,41 \\
\hline-11 & 6,07 & 3,59 & 5,76 & 7,34 & 5,46 & 11,25 \\
\hline-10 & 5,82 & 3,54 & 5,52 & 7,22 & 5,22 & 11,07 \\
\hline-9 & 5,58 & 3,49 & 5,28 & 7,12 & 4,99 & 10,91 \\
\hline-8 & 5,34 & 3,44 & 5,05 & 7,02 & 4,75 & 10,74 \\
\hline-7 & 5,11 & 3,39 & 4,82 & 6,91 & 4,52 & 10,59 \\
\hline-6 & 4,88 & 3,34 & 4,59 & 6,82 & 4,30 & 10,44 \\
\hline-5 & 4,65 & 3,29 & 4,36 & 6,72 & 4,07 & 10,28 \\
\hline-4 & 4,42 & 3,24 & 4,14 & 6,61 & 3,85 & 10,12 \\
\hline-3 & 4,20 & 3,20 & 3,92 & 6,52 & 3,63 & 9,97 \\
\hline-2 & 3,98 & 3,15 & 3,70 & 6,41 & 3,42 & 9,81 \\
\hline-1 & 3,76 & 3,10 & 3,49 & 6,32 & 3,21 & 9,65 \\
\hline 0 & 3,55 & 3,05 & 3,27 & 6,21 & 3,00 & 9,49 \\
\hline 1 & 3,34 & 3,00 & 3,07 & 6,10 & 2,79 & 9,32 \\
\hline 2 & 3,13 & 2,95 & 2,86 & 6,00 & 2,59 & 9,16 \\
\hline 3 & 2,93 & 2,90 & 2,66 & 5,89 & 2,39 & 8,99 \\
\hline 4 & 2,73 & 2,85 & 2,46 & 5,79 & 2,19 & 8,84 \\
\hline 5 & 2,53 & 2,80 & 2,26 & 5,69 & 2,00 & 8,68 \\
\hline 6 & 2,33 & 2,75 & 2,07 & 5,59 & 1,81 & 8,52 \\
\hline 7 & 2,14 & 2,70 & 1,88 & 5,49 & 1,62 & 8,37 \\
\hline 8 & 1,95 & 2,65 & 1,69 & 5,39 & 1,44 & 8,21 \\
\hline 9 & 1,77 & 2,60 & 1,51 & 5,29 & 1,26 & 8,06 \\
\hline 10 & 1,58 & 2,56 & 1,33 & 5,20 & 1,08 & 7,92 \\
\hline 11 & 1,40 & 2,51 & 1,15 & 5,10 & 0,90 & 7,76 \\
\hline 12 & 1,23 & 2,47 & 0,98 & 5,00 & 0,73 & 7,62 \\
\hline
\end{tabular}


Układ kogeneracyjny przy współpracy pomp ciepła z kotłownią olejową i siecią... 343

Tabela 3. Energia elektryczna wytworzona z odzysku ciepła odpadowego ze spalin kotłowych oraz energia elektryczna potrzebna do napędu pomp ciepła

Table 3. Electricity produced from the recovery of waste heat from boiler fumes and electricity necessary to propel a heat pump

\begin{tabular}{|c|c|c|c|c|c|c|c|}
\hline \multirow{2}{*}{\begin{tabular}{|c|} 
Czas trwa- \\
nia ze- \\
wnętrznej \\
temperatury \\
otoczenia \\
{$[\mathrm{h} / \mathrm{a}]$} \\
\end{tabular}} & \multirow{2}{*}{\begin{tabular}{|c|} 
Temperatu- \\
ra ze- \\
wnętrzna \\
otoczenia \\
$T_{o t}$ \\
{$\left[{ }^{\circ} \mathrm{C}\right]$} \\
\end{tabular}} & \multicolumn{2}{|c|}{$Q_{P C}=13,5 \mathrm{~kW}$} & \multicolumn{2}{|c|}{$Q_{P C}=27,0 \mathrm{~kW}$} & \multicolumn{2}{|c|}{$Q_{P C}=40,5 \mathrm{~kW}$} \\
\hline & & $\begin{array}{c}\text { Energia } \\
\text { wytwo- } \\
\text { rzona } \\
\text { [kWh/a] }\end{array}$ & $\begin{array}{c}\text { Energia } \\
\text { potrzebna }\end{array}$ & $\begin{array}{c}\text { Energia } \\
\text { wytwo- } \\
\text { rzona } \\
{[\mathrm{kWh} / \mathrm{a}]}\end{array}$ & $\begin{array}{c}\text { Energia } \\
\text { potrzebna }\end{array}$ & $\begin{array}{c}\text { Energia } \\
\text { wytwo- } \\
\text { rzona } \\
\text { [kWh/a] }\end{array}$ & $\begin{array}{c}\text { Energia } \\
\text { potrzebna }\end{array}$ \\
\hline \begin{tabular}{|l|}
24 \\
\end{tabular} & -16 & 176 & 92 & 168 & 189 & 161 & 290 \\
\hline 24 & -15 & 170 & 91 & 162 & 186 & 155 & 286 \\
\hline 24 & -14 & 164 & 90 & 156 & 184 & 149 & 282 \\
\hline 24 & -13 & 158 & 89 & 150 & 181 & 143 & 278 \\
\hline 24 & -12 & 152 & 87 & 144 & 179 & 137 & 274 \\
\hline 24 & -11 & 146 & 86 & 138 & 176 & 131 & 270 \\
\hline 48 & -10 & 279 & 170 & 265 & 347 & 251 & 531 \\
\hline 60 & -9 & 335 & 209 & 317 & 427 & 299 & 654 \\
\hline 36 & -8 & 192 & 124 & 182 & 253 & 171 & 387 \\
\hline 72 & -7 & 368 & 244 & 347 & 498 & 326 & 762 \\
\hline 72 & -6 & 351 & 241 & 330 & 491 & 309 & 751 \\
\hline 96 & -5 & 446 & 316 & 419 & 645 & 391 & 986 \\
\hline 120 & -4 & 531 & 389 & 497 & 794 & 462 & 1214 \\
\hline 144 & -3 & 605 & 460 & 564 & 938 & 523 & 1435 \\
\hline 168 & -2 & 669 & 529 & 622 & 1078 & 574 & 1647 \\
\hline 192 & -1 & 723 & 595 & 669 & 1213 & 616 & 1853 \\
\hline 264 & 0 & 937 & 805 & 864 & 1639 & 792 & 2504 \\
\hline 312 & 1 & 1042 & 935 & 957 & 1904 & 871 & 2908 \\
\hline 360 & 2 & 1128 & 1061 & 1030 & 2159 & 932 & 3297 \\
\hline 432 & 3 & 1265 & 1251 & 1149 & 2545 & 1033 & 3885 \\
\hline 504 & 4 & 1374 & 1435 & 1240 & 2919 & 1106 & 4455 \\
\hline 696 & 5 & 1760 & 1947 & 1576 & 3959 & 1392 & 6039 \\
\hline 456 & 6 & 1064 & 1254 & 944 & 2548 & 825 & 3886 \\
\hline 336 & 7 & 719 & 907 & 632 & 1844 & 545 & 2881 \\
\hline 264 & 8 & 515 & 700 & 447 & 1422 & 379 & 2168 \\
\hline 240 & 9 & 424 & 625 & 363 & 1270 & 301 & 1934 \\
\hline 240 & 10 & 380 & 615 & 319 & 1248 & 259 & 1901 \\
\hline 240 & 11 & 337 & 603 & 277 & 1223 & 217 & 1863 \\
\hline 240 & 12 & 294 & 592 & 235 & 1201 & 175 & 1828 \\
\hline & $\Sigma=$ & 16701 & 16542 & 15164 & 33659 & 13626 & 51379 \\
\hline & & \multicolumn{2}{|c|}{$U_{e P C}=1,010$} & \multicolumn{2}{|c|}{$U_{e P C}=0,451$} & \multicolumn{2}{|c|}{$U_{e P C}=0,265$} \\
\hline
\end{tabular}

gdzie: $U_{e P C}-$ udział energii elektr. wytworzonej w sezonie grzewczym z odzysku ciepła odpadowego w pokryciu zapotrzebowania do napędu pomp ciepła. 
Dla każdego wariantu współpracy kotłowni z pompami ciepła obliczono moc i energię elektryczną wytworzoną z odzysku ciepła za pośrednictwem silnika Stirlinga (w tabelach: kolumny zatytułowane: „Moc wytworzona” i „Energia wytworzona") oraz rzeczywistą moc i energię elektryczną potrzebną do napędu pomp ciepła (w tabelach: kolumny zatytułowane: „Moc potrzebna. Wartość rzeczywista” i „Energia potrzebna”). Obliczenia są wykonane dla całego zbioru wartości zewnętrznej temperatury otoczenia.

\section{Podsumowanie}

Analizując wyniki obliczeń zestawione w tabeli 2 i 3 dotyczących odpowiednio mocy i energii elektrycznej wytworzonych z odzysku ciepła odpadowego ze spalin kotłowych oraz mocy i energii elektrycznej potrzebnych do napędu pomp ciepła stwierdzono, że występują pewne zależności badanych parametrów technicznych. Porównując ich wielkości można scharakteryzować efektywność wariantów obliczeniowych z uwzględnieniem wykorzystania silnika Stirlinga.

1. Wzrost mocy zainstalowanej pomp ciepła powoduje:

a) wzrost mocy elektrycznej oraz wzrost energii elektrycznej zużytej do napędu pomp ciepła;

b) obniżenie wytworzonej mocy i energii elektrycznej uzyskanej z odzysku ciepła odpadowego.

2. We wszystkich wariantach obliczeniowych udział energii elektrycznej do napędu pomp ciepła, wytworzonej z odzysku ciepła odpadowego, liczony dla całego sezonu grzewczego, jest mniejszy od jedności. Wniosek jest taki, że do napędu pomp ciepła konieczny jest pobór energii elektrycznej z systemu elektroenergetycznego przez cały sezon grzewczy, a w wariancie z pompami ciepła o mocy zainstalowanej $13,5 \mathrm{~kW}$ - przez część sezonu grzewczego. Udziały energii elektrycznej maleją ze wzrostem mocy zainstalowanej pomp ciepła.

3. W wariancie współpracy kotłowni, w którym moc zainstalowana pomp ciepła jest równa 13,5 kW, w części sezonu grzewczego, w której zewnętrzna temperatura otoczenia jest nie wyższa niż $3^{\circ} \mathrm{C}$, wytworzona moc elektryczna z odzysku ciepła odpadowego jest większa niż moc zapotrzebowana do napędu pomp ciepła. Występuje tu nadwyżka wytworzonej mocy i energii elektrycznej, którą będą zasilane inne odbiorniki energii elektrycznej w GWSA. Gdy zewnętrzna temperatura otoczenia jest wyższa od $3^{\circ} \mathrm{C}$, wytworzona moc i energia elektryczna jest mniejsza od zapotrzebowanej do napędu pomp ciepła. Konieczny jest wówczas pobór energii z sieci elektroenergetycznej.

4. W wariantach współpracy o mocy zainstalowanej pomp ciepła równej $27,0 \mathrm{~kW}$ i większej wytworzona moc i energia elektryczna z odzysku ciepła odpadowego jest mniejsza od wartości zapotrzebowanych w całym sezonie grzewczym. Różnice pomiędzy mocą i energią wytworzoną a zapotrzebowaną wzrastają ze wzrostem zainstalowanej mocy pomp ciepła. 
Przedstawiona problematyka układu kogeneracyjnego przy współpracy pomp ciepła $\mathrm{z}$ kotłownią olejową i siecią ciepłowniczą ma istotny wpływ na uwarunkowania ekonomiczne i ekologiczne. Do rozwoju nowych technologii wdrażanych w energetyce cieplnej uwzględniane są również źródła energii odnawialnej. Zastosowanie układu kogeneracyjnego ma szczególne znaczenie w systemach ciepłowniczych.

\section{Literatura}

[1] Kusto Z.: Uwarunkowania ekonomicznej efektywności pomp ciepła, Wyd. IMP PAN, Gdańsk 2006.

[2] INSTAL-ROGRA. Technika Grzewcza i Sanitarna; http://www.instalrogra.pl /index.php?page=produkty\&kat=Viessmann, listopad 2011.

[3] Viessmann. Climate of innovation; http://www.viessmann.pl/pl/service/itemap. html, http://www.viessmann.pl/pl/obiekty-przemyslowe/systemy-grzewcze.html, http://www.viessmann.pl/pl/dom_wielorodzinny/systemy-grzewcze/kotlyolejowe.html, listopad 2011.

[4] Wytyczne projektowe: Paromat, Turbomat und Vitoplus Abgas/WasserWarmetauscher. VIESSMANN. 5811 046-4, 2/2000.

[5] Żmudzki S.: Silniki Stirlinga. Wydawnictwa Naukowo-Techniczne, Warszawa 1993.

[6] American Stirling Company; http://www.stirlingengine.com/fullpower, http://stirlingengine.com/links, sierpień-październik 2011.

[7] Backhaus S., Swift G.: New varieties of thermoacoustic engines. LA-UR-02-2721, 9th International Congress on Sound and Vibration, Los Alamos NM 87545, July 2002.

[8] Dancette M., Wintrebert G.: Etude et realisation d'un modele sur table de moteur Stiring de $3 \mathrm{~kW}$ scelle a sortie electrique. Raport Final. Commission des Communautés Européennes. EUR 9444 FR, 1984.

[9] Micro-Cooling, Heating, and Power (m-CHP) Instructional Module. United States Department of Energy (DOE), Mississippi Cooling, Heating, and Power (microCHP) and Bio-fuel Center. Mississippi State, MS 39762. December 2005.

[10] Stirling DK; http://www.stirling.dk, wrzesien-listopad 2011.

[11] Stirling Leistungsmotoren; http://www.stirlingmotor.com/leistungsmot.html, październik 2011.

[12] Stirling Technology Inc; http://www.stirling-tech.com, listopad 2011.

[13] Technische Dokumentation SOLO STIRLING 161 microKWK-Modul. Version 1.9 für Planer. SOLO STIRLING GmbH, Sindelfingen Juli 2003.

[14] Thomas B.: Application of internal wave form heat exchangers to Stirling engines. Stirling-Engineering Karl Kocsisek. Reutlingen 29.07.05.

[15] Tyagi S.K., Kaushik S.C., Singhal M.K.: Parametric study of irreversible Stirling and Ericsson cryogenic refrigeration cycles. Energy Conversion and Management 43 (2002) 2297-2309. 


\section{CHP SYSTEM COMBINING HEAT PUMPS, OIL BOILER AND HEATING NETWORK}

\section{S u m m a r y}

The article presents applicability of CHP system combining heat pumps, oil boilers and heating network. The research includes waste heat recovery by means of the Stirling engine. Recovered waste heat is used to propel Stirling engine, which propels a generator of electricity. Energy balance was calculated. Calculating average temperature of fumes $T_{s r}$ and ambient temperature $T_{o t}$ allowed to find actual efficiency of the Stirling engine. Calculated energy balance estimates the amount of electricity which is possible to generate. This amount varies significantly depending on the ambient temperature. In this case the energy balance is calculated for the situation in which a boiler is able on its own to fully cover the demand of heat. The cooperation between boilers and heat pumps was characterized. Five different variants of cooperation were considered, in each variant a heat pump has a different power. In each variant different parameters of electric power and energy from recovered heat were obtained. The energy produced in this way can be used either to propel the heat pump or to cover other needs. The author conducted the analysis of calculation results concerning the electric power and energy produced from the recovered waste heat from boiler fumes as well as electric power and energy necessary to propel heat pumps. The results of the analysis (Table 1) concerning the electric power and energy produced during a heating season show that the general electric energy obtained from the recovered waste heat from boiler fumes is $E_{e l}=18238,88 \mathrm{kWh} / \mathrm{a}$. Moreover, the highest mechanic power of the Stirling engine, obtained from the waste heat from the fumes is $N_{m s t i r}=8,04 \mathrm{~kW}$.

Keywords: energy balance, Stirling engine, heat recovery, boiler fumes, power, energy.

Przestano do redakcji: 09.04.2015 $r$.

Przyjęto do druku: 22.06.2015 r.

DOI:10.7862/rb.2015.62 